Ann. Biol. anim. Bioch. Biophys., I972, 12 (I), 77-89.

\title{
THE INFLUENCE OF SOYBEAN MEAL SUPPLEMENTED TO THE MAIZE DIET OF FORCED-FED GEESE UPON THEIR LIVER, ORGAN AND BLOOD PLASMA COMPONENTS
}

\author{
I. NIR, M. PEREK and Z. KATZ ( $\left.{ }^{1}\right)$ \\ Department of Animal Hygiene and Poultry Science, \\ The Hebrew University, Jerusalem, \\ Faculty of Agriculture, Rehovot (Israël)
}

\section{SUMMARY}

The effect of protein supplementation (ro p. roo soymeal) to cooked maize diet of forced-fed geese, on fatty liver weight and composition, abdominal adipose tissue, muscles, various organs and blood plasma was studied. The average I I $\mathrm{p}$. Ioo increase in liver weights obtained in the soymeal supplemented birds was concomitant with higher fat and lower protein concentrations. Protein supplementation seemed to accelerate liver fat accumulation while lowering abdominal a dipose tissue weight and fat concentration in the muscles. The plasma proteins' electrophoretic pattern of the protein supplemented geese showed a faster decrease in plasma albumins and a parallel increase in $\beta$-globulins. Their liver weights were found to be correlated to both the final body and abdominal adipose tissue weights, and their adrenal weights were significantly lower than the controls'. The possible causes of fatty liver formation in the forced-fed goose are discussed.

\section{INTRODUCTION}

Cooked maize, the main diet used in cramming geese for fatty liver production, is low in protein and lipotrophic factors such as choline and methionine. Fatty liver development is promoted by the above dietary deficiencies (Channon and Wilkinson, I935; Best and Channon, I935 ; TuCker and ECKstern, I937).

In field experiments carried out by the authors (unpublished) it was found that supplementation of I p. IOO choline or $0.4 \mathrm{p}$. IOo methionine to the maize diet did not inhibit hepatic steatosis and liver weights in the forced-fed geese. In a previous

(1) Extension Service, Ministry of Agriculture, Israël. 
report, NIR and PEREK (I97I) pointed out that the electrophoretic blood plasma protein patterns in forced-fed geese indicated a state of protein deficiency which was not influenced by high protein diets administered during the pre-fattening period.

Since, in the crammed goose, the liver's total protein content increases during the forced-feeding period (LECLERCQ, DURAND, DELPECH and BLUM, I968; SzYIIT, LECLERCQ and IVOREC SSYLIT, I968; NIR and PEREK, I97I), it was considered worthwhile to examine the effect of supplementing soymeal as a protein of high biological value, to the maize diet.

\section{EXPERIMENTAL}

Day-old goslings of a local breed (NrR and Perek, I97I) were fed a 22 p. IOO protei $i_{\perp}$ starter mash for 4 weeks and a $16 \mathrm{p}$. Ioo protein pelleted feed with a free access to out green alfalfa for the following 7 weeks.

At I I weeks of age, I ro geese, divided at random into 2 equal groups, were individually weighed, numbered and placed in cages for the forced-feeding experiment. The control group's basal diet consisted of cooked maize supplemented with vitamins, salt and $\mathrm{r}$ p. roo soy-oil according to Nir and Perek (I97I). The experimental diet was supplemented with Io p. Ioo (air dry basis) toasted soymeal (44 P. 10o protein plus $0.26 \mathrm{p}$. Ioo added synthetic DL-methionine).

Individual weights were taken weekly and blood samples were drawn from the wing vein of 6 random geese per group. Following individual slaughter when the oesophagi ceased to empty between meals (after 4-5 weeks of cramming) the carcasses were refrigerated for 24 hours, and liver and abdominal adipose tissue weights were recorded.

Additionally, 6 geese per group ( 3 of each sex) were sacrificed after 30 days of forced-feeding for weight determination (fresh tissue) of their organs which were immediately frozen on dry ice for chemical analysis.

\section{Care of tissues and chemical analyses}

Tissue preparation and chemical analyses were performed as described by NIR and PEREK (197I) and determination of free-fatty acids (FFA) in the plasma according to Dore (I956). For vitamin $\mathrm{C}$ determination, the adrenals were homogenized in $\mathrm{I}:$ Io $\mathrm{W}: \mathrm{V}$ water $; 2 \mathrm{ml}$ of the homogenate were mixed with $4 \mathrm{ml}$ of $\mathrm{H}_{2} \mathrm{O}$ followed by $2 \mathrm{ml} 5 \mathrm{p}$. Ioo sodium tungstate and $2 \mathrm{ml}$ $\mathrm{N} / 3 \mathrm{H}_{2} \mathrm{SO}_{4}$. The tubes were then centrifuged, and $2 \mathrm{ml}$ aliquot of the clear supernatant were titrated with 2.6 dichlorophenol indophenol. Determination of cholesterol in the adrenals was done on the same homogenates by the plasma method previously described by the authors (1971).

\section{Histology of livers and cell size measurements}

Fresh samples, taken from the caudal part of the right liver lobe, (I $\mathrm{cm}$ from the crest) were fixed in $10 \mathrm{p}$. Ioo neutral formalin. Duplicate frozen sections (IO-I $5 \mu$ ) were stained with Sudan Black B and Nuclear Fast red, according to Chifelle and Putt (195I). Parallel stained sections were dehydrated in serial ethanol solutions, from 70 to soo p. Ioo and washed in xylene, thus removing the fat and Sudan Black and leaving the fast red stained reticulum and nuclei. The longest distance between cell walls were measured at random in each section ( 75 cells per section).

\section{RESULTS}

\section{Body, liver and abdominal adipose tissue weights (table I)}

Even though during the first 4 weeks of cramming, the experimental group of birds showed a significant increase in body weight over the controls, no difference was noted at slaughter. It has to be emphasized that the experimental birds reached 
their slaughter weights 2.3 days earlier than the controls. Both groups consumed a similar amount of feed.

The liver weights obtained in both groups did not differ from those obtained in practice. While the average liver weights in the experimental group were II p. Ioo

\section{TABLE I}

The effect of soybean meal supplementation to maize during forced-feeding, on body gain, liver and abdominal adipose tissue weights and Liver/Abdominal adipose tissue ratio (49 geese per treatment)

Effet d'une supplémentation en farine de soja au régime, à base de maïs, des oies gavées, sur la prise du poids, les poids des tissus adipeux du foie et de l'abdomen et le rapport tissu adipeux du foie sur tissu adipeux de l'abdomen (49 oies pour chaque traitement)

\begin{tabular}{|c|c|c|c|c|}
\hline \multirow{2}{*}{ Variable } & \multicolumn{4}{|c|}{ Treatments means } \\
\hline & Maize & $\begin{array}{c}\text { Maize } \\
\text { soymeal }\end{array}$ & S. E. & F. \\
\hline \multicolumn{5}{|l|}{ Body weight (g) } \\
\hline Initial $\ldots \ldots \ldots \ldots \ldots$ & 4163 & 4190 & 59.5 & 0.10 \\
\hline 1 week forced-feeding & 4551 & 4721 & 57.7 & $8.708 * *$ \\
\hline 2 weeks - - & 5057 & 5260 & 62.8 & $8.525^{* *}$ \\
\hline 3 weeks - & 5828 & 6136 & 69.9 & $12.150 * *$ \\
\hline 4 weeks - - & 6660 & 7088 & 81.9 & $12.61^{*}$ \\
\hline Slaughter body weight & 7479 & 7457 & 103.6 & 0.02 \\
\hline $\begin{array}{r}\text { Forced-feeding period } \\
\text { (days) } \ldots \ldots \ldots \ldots \ldots\end{array}$ & 34.2 & 31.9 & 0.45 & $12.10^{* *}$ \\
\hline $\begin{array}{l}\text { Liver weight }(\mathrm{g}) \ldots . . . \\
\text { Abdominal }\end{array}$ & 576.1 & 653.1 & 21.10 & $6.67 * *$ \\
\hline $\begin{array}{c}\text { tissue weight }(\mathrm{g}) \ldots \\
\text { Ratios }\end{array}$ & 490.2 & 462.0 & 11.7 & 2.92 \\
\hline $\begin{array}{l}\text { Liver, } \% \text { body weight } \\
\text { Abdominal adipose tis- }\end{array}$ & 7.35 & 8.33 & 0.24 & $8.16^{* *}$ \\
\hline $\begin{array}{r}\text { sue, } \% \text { body weight } \\
\text { Liver/Abdominal. . . . . }\end{array}$ & 7.1 & 6.0 & 0.1 & $4.27 *$ \\
\hline adipose tissue weight & 1.21 & 1.43 & 0.05 & $9.82 * *$ \\
\hline Feed consumed (air-dry) & & & & \\
\hline Maize $(\mathrm{kg} /$ goose $) .. .$. & 23.0 & 21.1 & & \\
\hline Soymeal (kg/goose)... & - & 2.1 & & \\
\hline
\end{tabular}

$a 44$ p. 100 protein soymeal enriched with 0.26 p. 100 DL-méthionine.

* Statistically significant $\mathrm{P}<\mathbf{0 . 0 5}$.

** $\mathrm{P}<0.01$.

higher than the control's ( 653 and $576 \mathrm{~g}$ respectively), their abdominal adipose tissue weight expressed as a percentage of body weight, was lower to a degree statistically significant (7.I and 6.0 p. I0o). The ratio Liver/Abdominal adipose tissue weight in the control and experimental groups was I.2I and I.43 respectively. 
Marginal and partial correlations between body, liver and abdominal adipose tissue weights and days of fattening (tables $2 a$ and $2 b$ )

Both marginal and partial correlations were computed for each pair of variables in the experimental and control groups. In both groups fairly high marginal corre-

TABIE $2 a$

Marginal and partial correlation coefficient matrix of some variables in the control group

(maize fed) presented in table $\mathrm{I}$

Matrice du coefficient de corrélation marginal et partiel de quelques variables chez le groupe témoin (nourri au mais) présenté dans le tableau 1

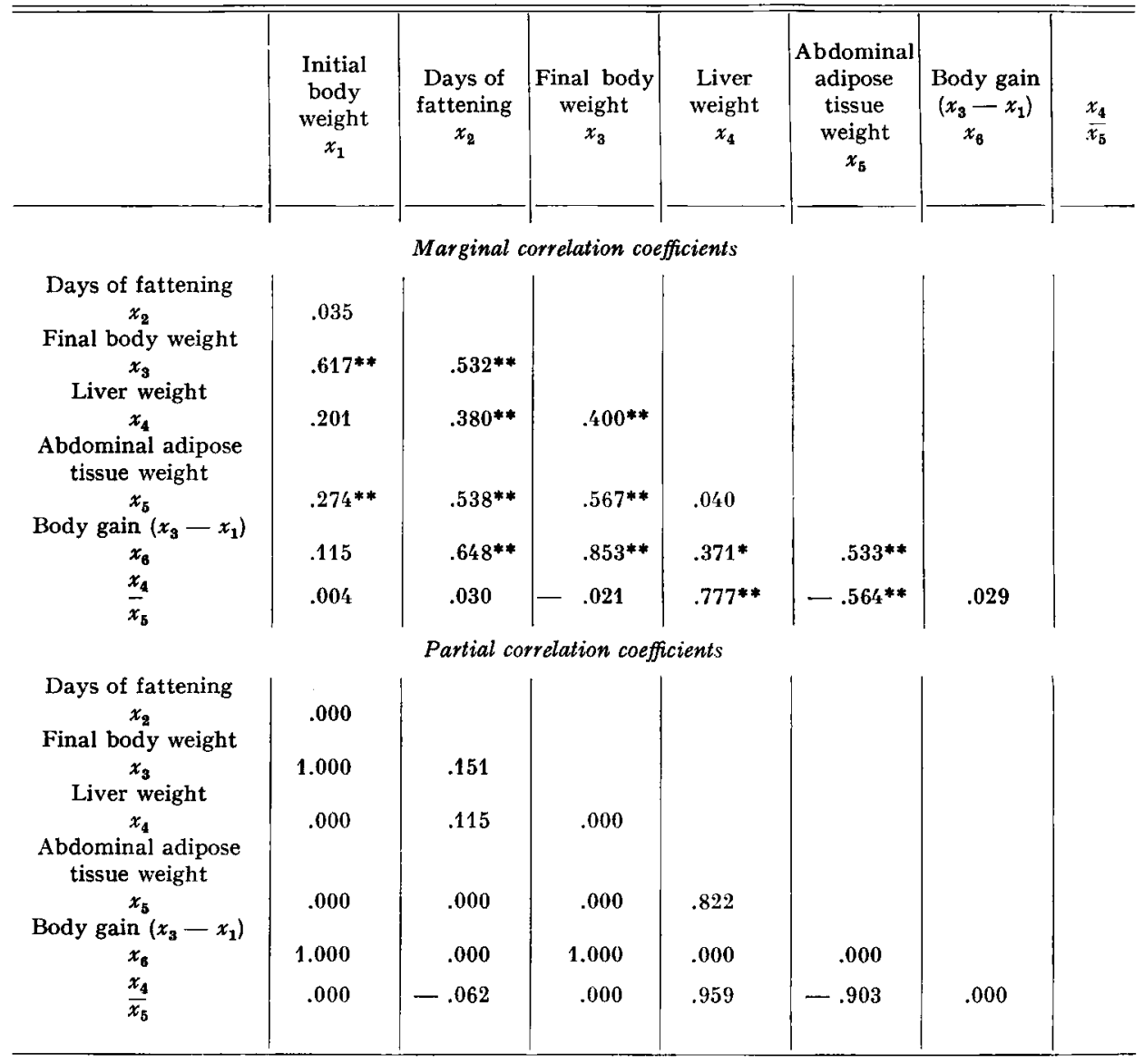

* Statistically significant $P<0.05$.

** Highly statistically significant $\mathrm{P}<0.01$. 
lations were found between body gain $\left(x_{6}\right)$, final body weight $\left(x_{3}\right)$ and days of fattening $\left(x_{2}\right)$; but whereas a correlation was found between the Initial $\left(x_{1}\right)$ and Final $\left(x_{3}\right)$ weights, none was found between body gain $\left(x_{6}\right)$ and the Initial weight $\left(x_{1}\right)$.

\section{TABLE $2 b$}

Marginal and partial correlation coefficient matrix of some variables in the experimental group (maize + soymeal fed) presented in table 1

Matrice du coefficient de carrélation marginal et particl quelques variables chez le groupe expérimental (nourri au maïs et farine de soja) présenté dans le tableau 1

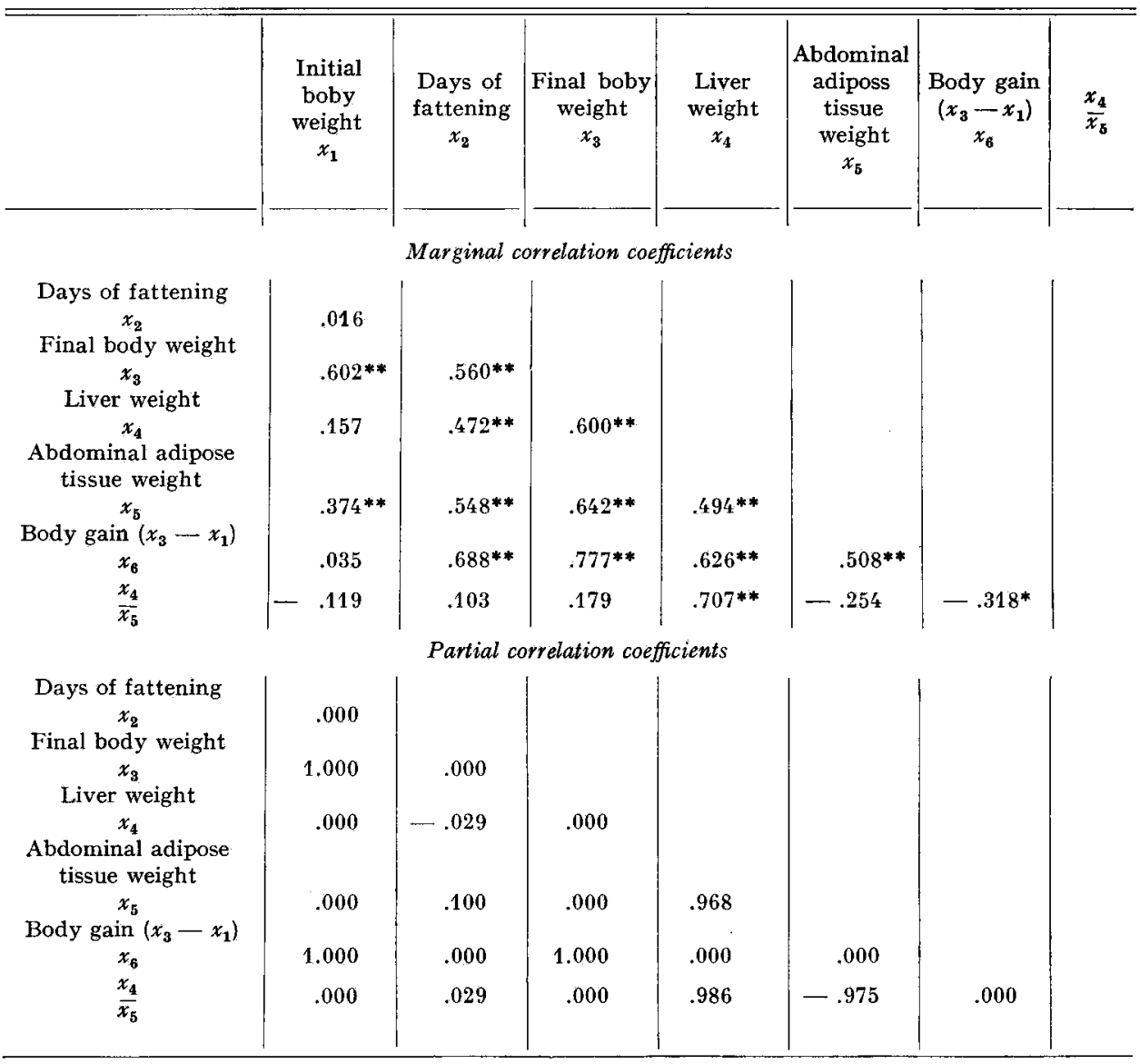

*Statistically significant $P<0.005$.

** Highly statistically significant $\mathrm{P}<0.01$.

In both groups, a marginal correlation was found between abdominal adipose tissue weight $\left(x_{5}\right)$, final weight $\left(x_{3}\right)$, body gain $\left(x_{6}\right)$ and days of fattening $\left(x_{2}\right)$, but the correlation between the adipose tissue weight $\left(x_{5}\right)$ and the Initial weight $\left(x_{1}\right)$ was very low. 
Liver weight $\left(x_{4}\right)$, was correlated to the ration Liver/Abdominal adipose tissue weights $x_{4} / x_{5}$ in both groups, and was less correlated to body gain $\left(x_{6}\right)$ in the control group as compared to the experimental group. Liver weight was correlated to the abdominal adipose tissue weight $\left(x_{5}\right)$ in the experimental group only.

Examination of the partial correlations table shows, as expected, that the Initial weight $\left(x_{1}\right)$, final weight $\left(x_{3}\right)$ and body gain $\left(x_{6}\right)$ are exactly linked by $x_{6}=x_{6}-x_{1}$.

High partial correlations lead to a dependence between liver weight $\left(x_{4}\right)$, abdominal adipose tissue weight $\left(x_{5}\right)$ and the ratio between them $x_{4} / x_{5}$.

It is interesting to note that, in fact, a very good relation was found between $x_{4} / x_{5}, x_{4}$ and $x_{5}$.

\section{Organ weights following 30 days of fattening}

(6 geese per treatment, table 3 )

At this period, both body and liver weights of the birds in the experimental group were higher than the control's, while their relative abdominal adipose tissue

\section{TABLE 3}

The effect of soybean-meal supplementation to maize during forced-feeding for a period of 30 days on organs weight and composition

(6 geese per treatment)

Les effets d'une supplémentation en farine de soja au régime à base de maïs, des oies gavées, pendant 38 jours, sur le poids et la composition des organes

(6 oies par traitement)

\begin{tabular}{|c|c|c|c|c|}
\hline \multirow{2}{*}{ Variable } & \multicolumn{4}{|c|}{ Treatment means } \\
\hline & Maize & $\begin{aligned} & \text { Maize } \\
+ & \text { soymeal }\end{aligned}$ & SE & $\mathbf{F}$ \\
\hline Body weight $(g) \ldots \ldots \ldots$ & 6470 & 7145 & 317.1 & $6.66^{*}$ \\
\hline Liver weight $(\%$ body $w.) \quad \ldots \ldots \ldots$ & 6.14 & 7.42 & 0.30 & $6.93^{*}$ \\
\hline Abdominal adipose tissue $(\%$ body w. $\ldots \ldots \ldots$ & 5.74 & 5.52 & 0.19 & 0.35 \\
\hline Kidneys weight (g/kg body w.) $\ldots \ldots \ldots \ldots \ldots \ldots$ & 6.1 & 7.2 & 0.5 & 0.87 \\
\hline Pancreas weight $(\mathrm{g} / \mathrm{kg}$ body w.) $\ldots \ldots \ldots \ldots \ldots$ & 1.35 & 1.24 & 0.07 & 1.51 \\
\hline Esophagus weight (g/kg body w.) $\ldots \ldots \ldots \ldots \ldots$ & 6.8 & 6.8 & 0.5 & 0.09 \\
\hline Thyroids weight $(\mathrm{mg} / \mathrm{kg}$ body w.) $\ldots \ldots \ldots \ldots \ldots$ & 46 & 45 & 3.8 & 0.08 \\
\hline Adrenals weight $(\mathrm{mg} / \mathrm{kg}$ body $\mathrm{w}.) \ldots \ldots \ldots \ldots \ldots$ & $16 !$ & 132 & 6.2 & $14.18^{* *}$ \\
\hline Liver total $\mathbf{N}(\%) \ldots \ldots \ldots \ldots \ldots \ldots \ldots \ldots \ldots \ldots$ & 1.64 & 1.30 & 0.09 & $8.92 * *$ \\
\hline Liver non protein $\mathrm{N}(\%) \ldots \ldots \ldots \ldots \ldots \ldots$ & 0.21 & 0.21 & 0.11 & 0.86 \\
\hline Liver total $\mathrm{N}$ (g/liver) $\ldots \ldots \ldots \ldots \ldots \ldots \ldots \ldots \ldots \ldots \ldots \ldots$ & 6.88 & 8.03 & 0.52 & 1.41 \\
\hline Kidneys total $N(\%) \ldots \ldots \ldots \ldots \ldots \ldots \ldots \ldots$ & 1.89 & 2.15 & 0.09 & 4.05 \\
\hline Kidneys non protein $\mathrm{N}(\%) \ldots \ldots \ldots \ldots \ldots$ & 0.34 & 0.36 & 0.03 & 0.31 \\
\hline Liver ether extract $(\%) \ldots \ldots \ldots \ldots \ldots \ldots \ldots$ & 46.1 & 50.6 & 1.65 & 2.12 \\
\hline Liver total cholesterol (mg \%) . . . . . . . . . . . . & 586 & 609 & 80.1 & 0.05 \\
\hline Liver lipid $P(\mathbf{m g} \%) \ldots \ldots \ldots \ldots \ldots \ldots \ldots \ldots \ldots \ldots \ldots$ & 110 & 104 & 9.1 & 0.27 \\
\hline Breast muscle ether extract $(\%) \ldots \ldots \ldots \ldots \ldots$ & 5.69 & 4.15 & 0.40 & $5.43^{*}$ \\
\hline Abdominal adipose tissue ether extract $(\%) \ldots \ldots \ldots$ & 94 & 92 & 3.6 & 0.06 \\
\hline 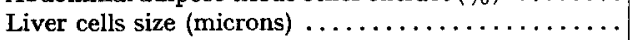 & 29.4 & 33.5 & $2.1=$ & 4.50 \\
\hline Adrenals vitamin $\mathrm{C}(\mathrm{mg} / \mathrm{g}$ tissue) $\ldots \ldots \ldots \ldots \ldots$ & 0.988 & 0.882 & 0.121 & 0.09 \\
\hline Adrenals total cholesterol (mg/g tissue) . . . . . . . & 49 & 49 & 3.1 & 0.05 \\
\hline
\end{tabular}


weights were the same. The experimental birds' adrenal weights were found to be lower to a high statistically significant degree. No significant differences in pancreas, kidney, oesophagus and thyroid weights were found between the groups. The geese were juvenile with underdeveloped gonads.

Selected chemical determinations of livers, abdominal adipose tissues, kidneys, breast muscles and adrenals, following 30 days of fattening ( 6 geese per treatment, table 3 )

While the higher total liver lipids found in the experimental birds (50.6 versus 46.I p. I00) was not statistically significant, the inverse decrease in the liver's nitrogen content (I.30 versus I.64 P. IOO) was found to be highly significant. This difference was due to protein nitrogen only since in both groups, the liver's non-protein $\mathrm{N}$ content was similar (0.2I p. Ioo). In spite of its reduced $\mathrm{N}$ concentration the total $\mathrm{N}$ content in the liver of the experimental birds was higher than the controls'. The difference ( 8.03 versus $6.88 \mathrm{~g} /$ /iver) even if not statistically significant, seems substantial.

The experimental group's total kidney $\mathrm{N}$ concentration was higher than the control's (2.I5 versus I. 89 p. IOo) with no difference in non-protein nitrogen concentrations ( 0.36 and 0.34 p. 100 respectively). There was no difference in the livers total cholesterol and lipid $\mathrm{P}$ concentrations between the groups. Both groups had a similar total lipid concentration in abdominal adipose tissue which was very high (over 9o p. Ioo). A statistically significant difference was noted in the breast muscle total lipid content (4.I5 p. Ioo in the experimental group and 5.69 p. Ioo in the control). The experimental group's lower adrenal weights were not accompanied by a change in cholesterol or vitamin $\mathrm{C}$ concentrations.

\section{Hematocrit, plasma sugar and plasma lipid values (fig. I)}

A decrease in the hematocrit values observed in the control group during the second week of fattening, returned to normal in the following weeks. The experimental group, on the other hand, showed steady hematocrit values throughout the fattening period. The plasma sugar levels decreased slightly during fattening and increased only in the last days of forced-feeding in both groups. All plasma lipids, triglycerides, total cholesterol, lipid $\mathbf{P}$ and free-fatty acids increased similarly in both groups.

\section{Blood plasma proteins (fig. 2)}

A slight increase in total blood plasma protein concentration in the experimental birds at the second week of cramming, dropped gradually, and reached the control levels at the end of the fattening period. While the difference in total plasma protein between the groups were transient, those in some plasma protein fractions remained consistent to the end of the experiment ; the general trend of $\beta$-globulin increase and albumin decrease (NIR and PEREK, I97I ; BLUM, GAUMETON, MUH and LECLERQ, I970) was enhanced by soymeal supplementation to the maize diet. The experimental group's $\alpha$-globulins, which were lower than the control's during the first and second 

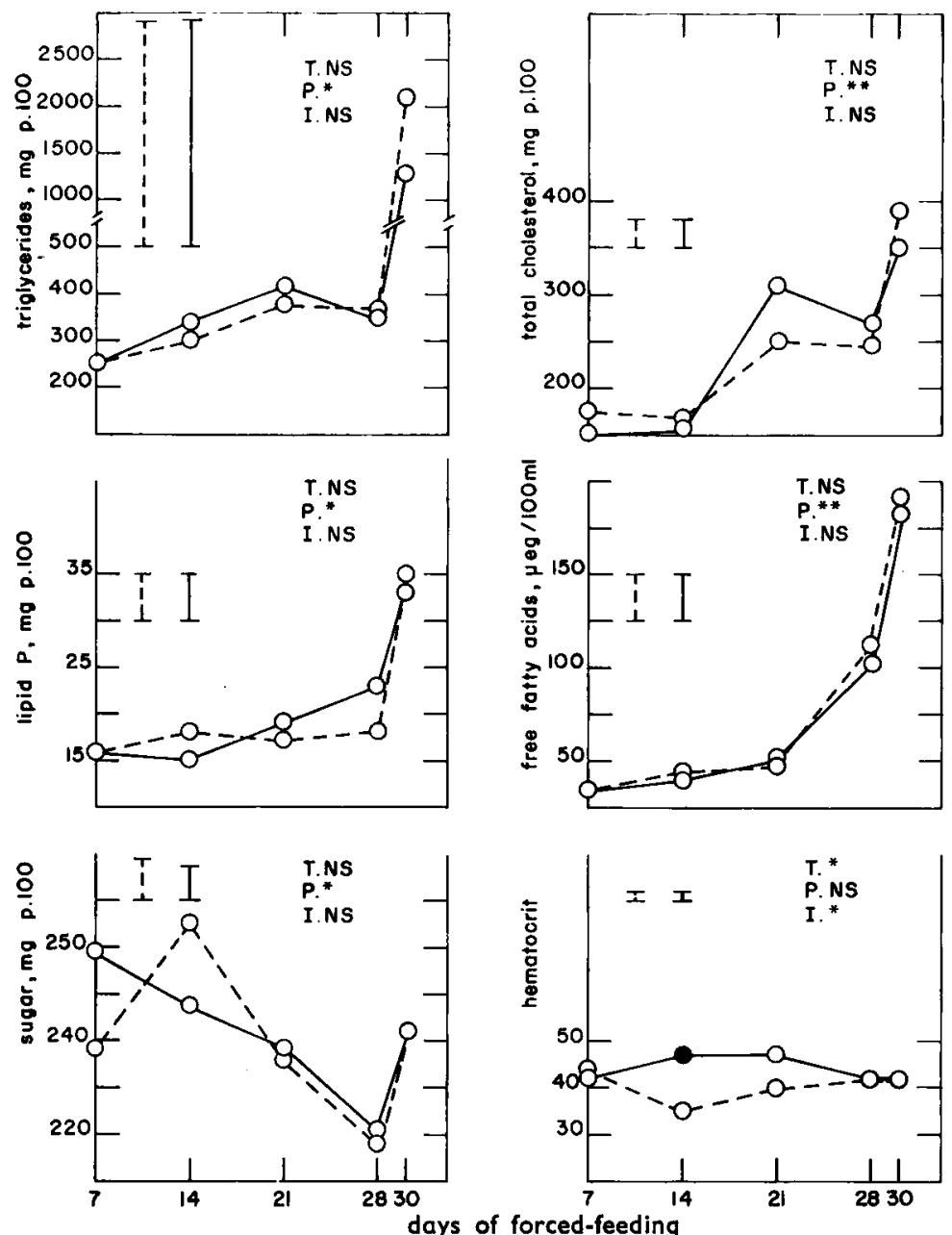

Fig. I. - Effect of Io $p$. Ioo soymeal supplementation to the basal diet of forced-fed geese on hematocrit, sugar and lipid components in blood plasma at different periods (6 geese per treatment, and period)

(P) Effect of Period

(T) Effect of Treatment ;

(I) Effect of Interaction between these two for the whole experimental period * $\mathrm{P}<0.05 ; \quad$ ** $\mathrm{P}<0.01$

- Statistically significant difference at the designed period

FIG. I. - Effet d'une supplémentation en farine de soja (Io p. Ioo) au régime de base des oies gavées sur l'hêmatocrite, les sucres et les lipides du plasma à différents moments (6 oies par traitement et par période)

$$
\begin{aligned}
& \text { - lot supplémenté } \\
& -- \text { lot témoin }
\end{aligned}
$$

T Effet du traitement

$P$ Effet de la période

I Effet de l'interaction entre les deux pour toute la période expérimentale

$* \mathrm{P}<0.05 * * \mathrm{P}<0,01$ 
weeks of forced-feeding, increased thereafter to the latter's level. Due to its high variation, no consistent deductions were drawn on the treatment's effect on $\gamma$-globulin concentrations.
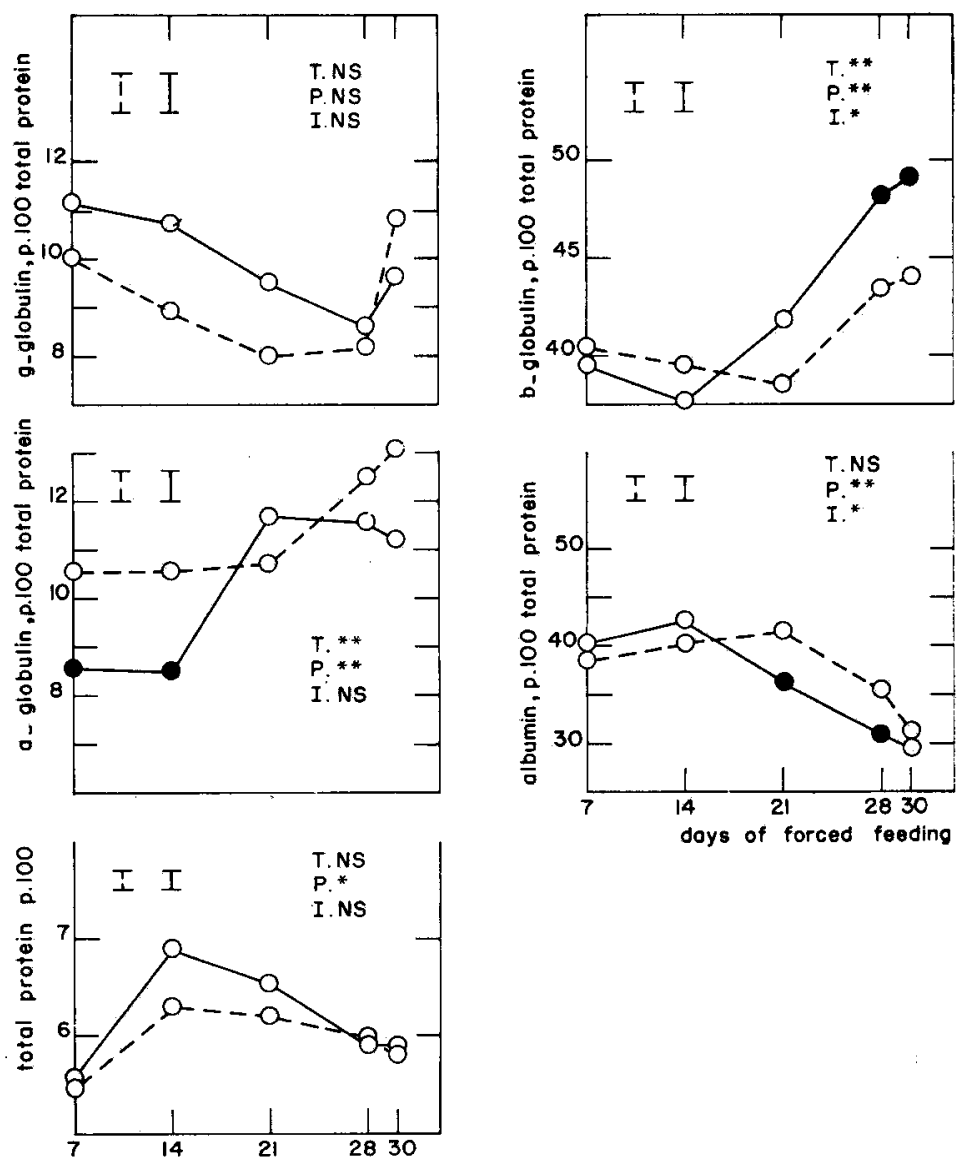

Frg. 2. - Effect of 1o $p$. Ioo soymeal supplementation to the basal diet of forced-fed geese on the amount of blood plasma protein and on the percentage of the different plasma protein fractions

- soymeal supplemented group

-- control group. (See legend of fig. I)

FIG. 2. - Effet d'une supplémentation en farine de soja (1о p. 10о) au régime de base des oies gavées sur les protéines totales du plasma et le pourcentage des différentes fractions protéiques du plasma

$\longrightarrow$ lot supplémenté

\section{Cell size and structure of fatty livers}

The histological picture was similar to that shown by LABIE and Tournut (I970). All the cells in both groups, were in a state of extreme adiposity (fig. 3). The cell membranes were left intact following solvent washing. No difference could be 
seen between the groups' liver cell structure, but, the experimental group's cells appeared to be larger than the control's (33.5 and 29.4 microns respectively, table 3). This difference, though not statistically significant, is in accordance with the liver's chemical values, since the experimental group's fat concentration was higher and protein nitrogen level lower than the control's.
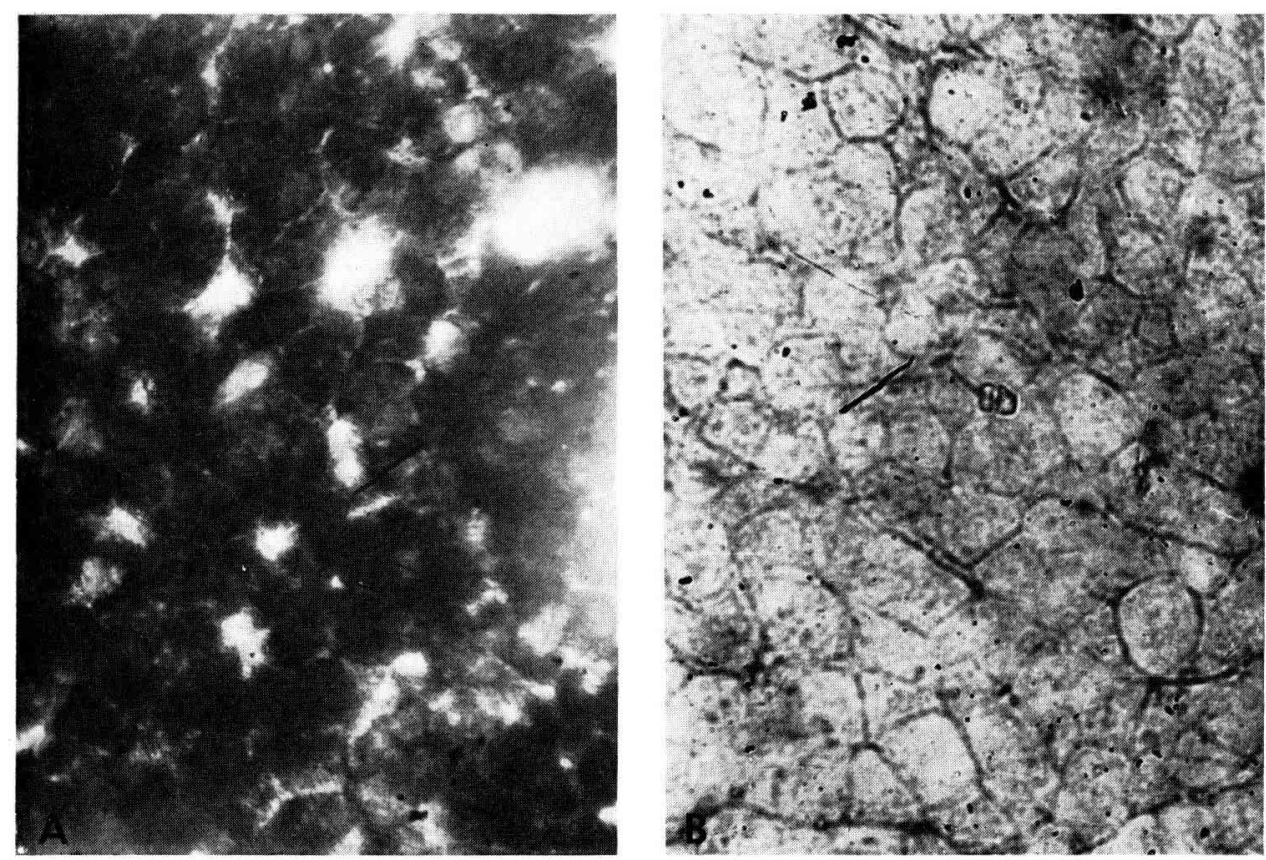

FIG. 3. - Representative liver sections stained with Sudan Black (A) and after washing the Sudan Black with Xylene (B) Zeiss obj. ro-oc 8.

No difference in the apparent liver cell structure could be seen between the groups In $B$ it can be seen that the cell membranes are intact

FIG. 3. - Coupes de foie colorées au noir Soudan (A) et après lavage du noir Soudan au xylène (B)

On ne voit pas de différence dans la structure des cellules du foie entre les deux groupes Sur la photo B on peut voir que les membranes cellulaires sont intactes

\section{DISCUSSION}

Various reviews on the physiology and pathology of the fatty liver syndrome deal mostly with rats (Physique, Pathologie, Chimie et Cytologie des foies gras, I953; LOMBARDI, I966; CLEMENT, I967; MACDONALD, I966). The pathogenesis of fatty liver production in geese is ethiologically different. Field experiments performed by the authors showed that adding I p. I0o choline or $0.4 \mathrm{p}$. Ioo Methionine to the maize diet did not interfere with the weights and quality of the fatty livers (unpublished). Furthermore, as demonstrated in the present study, the supply of ro p. roo 
soymeal to the diet even improved the liver weights of the crammed geese and increased somewhat its fat concentration.

Since White Leghorn hypothalamus lesioned cocks which became functionally castrated and hyperphagic produced enlarged fatty livers on a balanced laying mash (SNAPIR, NIR, FURUTA and LEPKOVSKY, I969) and normal forced-fed cocks produced steatic livers on the same mash (LEPKOVSKY, personal communication), it seems that liver steatosis in forced-fed geese is essentially caused by excessive caloric intake and not by dietary deficiencies.

Assuming that like in the pigeon (GoodRIDGE and BALL, I966-67) the main site of lipogenesis in the goose is the liver, one can deduce that the process of liver steatosis in geese is caused by a disparity between the high rate of hepatic fat synthesis and its mobilization from the liver to the extrahepatic tissues.

In the present study a high partial correlation was found between the fatty livers weights, the abdominal adipose tissue weights and the ratio between these two in the crammed geese. It may therefore be assumed that this dependence represents the ratio between extrahepatic and hepatic fat deposition, and was influenced by the addition of protein to the diet. This assumption may be sustained by the following findings in the soymeal supplemented group :

I. Significant less abdominal adipose tissue of similar fat concentration as compared to the control's.

2. Lower fat concentration in the breast muscles.

3. Larger livers, of higher fat and lower protein concentration (but similar total protein contents).

4. A higher Liver/Abominal adipose tissue ratio.

The technician who crammed the birds claimed that the experimental geese emptied their oesophagi faster than did the controls and less undigested maize particles were observed by the authors in their feces. It may be suggested, that addition of soymeal improved digestibility and therefore the birds were ready for slaughter earlier (2.3 days) than the controls.

Various stress reactions in birds cause adrenal hypertrophy (STURKIE, I965) and depletion of adrenal ascorbic acid and cholesterol in chickens (PEREK and EIrAT, I960; PEREK and BeDRAK, I962 ; FREeMAN, I967, I969, I970). The significant lower adrenal weights of the soymeal supplemented geese compared with the controls, may indicate a reduced stress condition, although no difference in vitamin $\mathrm{C}$ and cholesterol concentrations were noted.

Protein supplementation to the diet increased the total liver lipid concentration but no change in cholesterol and lipid phosphorus occurred. It is therefore obvious that the increased lipid fraction consisted mainly of triglycerides.

All plasma lipid fractions increased gradually during the first 4 weeks of forcedfeeding, showing a steep increase in the last 2 days before sacrifice. Plasma sugar and $\gamma$-globulins which decreased during the same period steeped up in the last 2 days (fig. I and 2 respectively). This may result from a critical condition, when the liver loses its full ability to regulate these components in the plasma.

The decrease in the plasma albumin fraction in the soymeal supplemented birds which was concomitant with higher liver weights is in accordance with the work of BLUM et al. (1970) who reported a negative correlation between liver weights and 
plasma albumin. The decrease in albumin may be of physiological importance in relation to FFA transportation which are albumin bound in the blood plasma. In contrast with the authors' previous study (NIR and PEREK, I97I) in which high protein diets during the preparatory period caused a decrease in plasma FFA before and during the fattening period, in the present work, adding protein during the fattening period did not influence this parameter.

BIELINSKr ( 1967$)$ found a correlation between the initial body weight of geese before cramming and the fatty liver weights following it. In the present study, no such correlation was found in either group ; on the other hand, a significant marginal correlation, between liver weights and body gains was found to be particularly high in the soymeal supplemented group (table $2 a$ and $2 b$ ).

Reçu pour publication en juillet 1971.

\title{
ACKNOWLEDGEMENT
}

This work was generously supported by the Louis Rubens Filigree Foundation Inc., U. S. A.

\section{RÉSUMÉ}

\author{
INFLUENCE, D'UNE SUPPLÉMENTATION EN FARINE DE SOJA \\ CHEZ DES OIES GAVÉES AU MAÏS, SUR IAA COMPOSITION DU FOIE, \\ DES ORGANES ET DU PLASMA SANGUIN
}

On a étudié l'effet d'une supplémentation protéique (Io p. Ioo de farine de soja) chez des oies gavées au maïs sur le poids et la composition du foie gras, sur le plasma sanguin, le tissu adipeux abdominal, les muscles, etc.

Le poids du foie augmente en moyenne de i I p. Ioo chez les oiseaux recevant du soja. Sa concentration en graisse est plus élevée et, en protéines, plus faible. La supplémentation protéique semble accélérer l'accumulation de graisse dans le foie et réduire le poids du tissu adipeux abdominal et la concentration de graisses dans les muscles. L'étude électrophorétique des protéines plasmatiques montre que la diminution des albumines est plus rapide chez les oies supplémentées en protéines; parallèlement les $\beta$-globulines augmentent.

Le poids du foie est lié au poids du corps et du tissu adipeux abdominal. Le poids des surrénales est significativement plus faible que chez les oiseaux témoins.

Les causes possibles de la formation des foies gras chez les oies gavées sont discutées.

\section{REFERENCES}

Best C. H., Channon H. J., I935. The action of choline and other substances in the prevention and cure of fatty livers. Biochem. J., 29, 265I-2658.

Blum J.-C., Gaumeton J.-P., Muh J.-P., Lecherce B., 197o. Modifications de la valeur des normes sanguines en fonction du degré de stéatose hépatique chez l'oie gavée. Ann. Rech. vêter., 1, I67-178.

Bielinski B., I967. The relationship between weight of fat liver and body weight of geese before fattening. Roczniki Nauk Rolniczych, 89, 4×3-418.

Channon H. J., Wilkinson H., I935. Protein and the dietary production of fatty livers. Biochem. $J ., 29,350-356$. 
Clément J., Clément G., I967. Données récentes de la stéatose hépatique. Cahiers Nutr. Diet., 2 , $4 I-47$.

Chifflle T. L., Putt F. A., 1951. Stain Tech, 26, 51 as described in Manual of Histologic staining methods of the armed forces Institute of Pathology. Third Ed. Am. Reg. Pathol. Lee G. Luna (Edit.) McGraw-Hill Book Co. N. Y., I968 p. 145.

Dole V. P., 1956. A relation between nonesterified fatty acids in plasma and the metabolism of glucose. J. Clin, Invest., 85, I50-I54.

FrEeman B. M., I967. Effect of stress on the ascorbic acid content of the adrenal gland of Gallus domesticus. Comp. Biochem. Physiol., 23, 303-305

Freeman B. M., I 969 . The bursa of Fabricius and adrenal cortical activity in Gallus domesticus. Comp. Biochem. Physiol., 29, 639-646.

FreEman B. M., I970. The effects of adrenocorticotrophic hormones on adrenal weight and adrenal ascorbic acid in the normal and bursectomized fowl. Comp. Biochem. Physiol. 32, 755-76r.

Goodridge A. G., Ball E. G., I966. Lipogenesis in the pigeon : in vitro studies. Amer. J. Physiol. 211, $803-808$.

Goodridge A. G., Ball E. G., 1967. Lipogenesis in the pigeon : in vivo studies. Amer. J. Physiol. 213, $245^{-249}$.

Labie C., Tournut G., I97o. Recherches sur les modifications histologiques et biochimiques chez les oies soumises au gavage. Cah. Méd. vét. 39, 247-26r.

Leclerce B., Durand G., Delpech P., Blum J.-C., I968. Note préliminaire sur l'évolution des constituants biochimiques du foie au cours du gavage de l'oie. Ann. Biol. Anim. Bioch. Biophys., 8, 549-556.

LOMBaRd B., I966. Considerations on the pathogenesis of fatty liver. Lab. Invest. 15, x, 1-20.

Mac Donald I., 1966. Lipid responses to dietary carbohydrates. II. Liver. Adv. Lip. Res. 4, 4I-48.

NIR I., PEREK M., I97x. The effect of various protein levels in feed of goslings during the preparatiry period in fatty liver production and blood plasma components. Ann. Biol. anim. Bioch. Biophys. (in press).

Perek M., Bedrak E., I962. The effect of cold and debeaking upon the adrenal ascorbic acid concentration of chickens fed aureomycin supplement. Poultry Sci., 41, I I49-II56.

PEREK M., EILAT A., I960. Effect of removal of bursa fabricii on depletion of adrenal ascorbic acid in ACTH-treated chicks. Endocrinology, 66, 304-305

Perek M., Eirat A., I96o. Physiologie, Pathologie Chimie et Cytologie des Foies gras, 1935. Les journées scientifiques du Centre National de coordination des études et recherches sur la nutrition et l'Alimentation. 5, $\mathrm{CI}_{\mathrm{I}} \mathrm{C}_{4} \mathrm{O} 4$.

Snapir. N., Nir I., Furuta F., Lepkovsky S., r969. Effect of administered testosterone propionate on cocks functionnally castrated by hypothalamic lesions. Endocrinology, 84, 611-618.

Sturkie P. D., r965. Avian physiology and ed. Bailliere, Tindall and Cassel, London, p. 672-677.

Szylit M., Leclerco B., Ivorec-Szydit O., I968. Relations spécifiques entre les lactodéhydrogénases du sérum et du foie chez l'Oie : détermination quantitative et caractérisation électrophorétique. C. R. Acad. Sc. (Paris), 266, $952-955$.

Tucker Hellen F., Eckstein H. G., r937. The effect of supplementary methionine and cystine on the production of fatty livers by diets. J. Biol. Chem., 121, 479-484. 